\title{
Development of a quality index scheme and shelf-life study for whole tambaqui (Colossoma macropomum)
}

\author{
Márcio Luís Bernardo Pontes da SILVA ${ }^{1,2}$, Jane Mello LOPES ${ }^{1}$, Sidely Gil Araújo VIEIRA², \\ Thaís Danyelle Santos ARAUJO², Rodrigo Maciel CALVET ${ }^{3}$, Alitiene Moura Lemos PEREIRA², \\ Fabiola Helena dos Santos FOGAÇA ${ }^{2, *}$ \\ Universidade Federal do Maranhão, Centro de Ciências Agrárias e Ambientais, Campus de Chapadinha, MA. Rodovia 222, Km 4, s/n, Bairro Boa Vista, 65500-000 \\ Chapadinha, MA, Brazil. \\ 2 Embrapa Meio-Norte, BR 343, km 35, 64200-970 Parnaiba, PI, Brazil \\ 3 Instituto Federal de Educação Superior, IFES, Caxias, MA, Brazil. \\ * Corresponding author: fabiola.fogaca@embrapa.br.
}

\section{ABSTRACT}

The study developed a sensory scheme based on the Quality Index (QI) and estimated the shelf-life for whole tambaqui, Colossoma macropomum (Cuvier, 1818), stored in ice, assessing and determining the most appropriate chemical, physical, bacteriological and quality sensory parameters and their changes during storage time. Ninety six fish were evaluated at $1,3,5,8,10,12,15$, 17, 19 and 22 days of ice-storage. The developed quality index (QI) showed four main quality attributes with a total of 29 demerit scores. The skin mucus and odor, as well as general appearance and ventral elasticity had a great importance for the statistical model applied, while eyes, gills mucus and dorsal elasticity showed lower significance for tambaqui QI. The $\mathrm{pH}$ showed few variations during the ice storage. The nitrogen bases, as well as the total count of specific spoilage bacteria, had a linear correlation with the storage time. The QI proved to be efficient to assess tambaqui quality and loss of sensory quality over the storage period. The results suggest that whole, ice-stored Colossoma macropomum is fit for consumption until the $22^{\text {nd }}$ day.

KEYWORDS: food quality, storage time, spoilage, sensory parameters

\section{Desenvolvimento do protocolo do Índice de Qualidade e estudo da vida útil do tambaqui}

\section{RESUMO}

O estudo desenvolveu um protocolo sensorial baseado no Método do Índice de Qualidade (IQ), estimando a vida útil do tambaqui, Colossoma macropomum, inteiro e conservado em gelo, avaliando e determinando as principais alteraçóes físicoquímicas, microbiológicas, os parâmetros sensoriais e suas alteraçôes durante o armazenamento em gelo. Noventa e seis peixes foram avaliados no dia $1,3,5,8,10,12,15,17,19$ e 22 de armazenamento em gelo. O índice de qualidade desenvolvido (IQ) apresentou quatro principais atributos de qualidade com um total de 29 pontos de demérito. O muco e odor da pele, assim como a aparência geral e elasticidade ventral, apresentaram uma maior importância para o modelo estatístico aplicado, enquanto que os olhos, muco das brânquias e elasticidade dorsal mostraram menor significância para o IQ do tambaqui. $\mathrm{O}$ pH apresentou poucas variaçóes durante o armazenamento em gelo. As bases nitrogenadas voláteis totais, bem como a contagem total de bactérias específicas de deterioração, apresentaram correlação linear com o tempo de armazenamento. O IQ mostrouse eficiente para avaliar a qualidade do tambaqui e as perdas da qualidade sensorial ao longo do período de armazenamento. Os resultados sugerem que o Colossoma macropomum inteiro e conservado em gelo é considerado adequado para consumo até o $22^{\circ}$ dia de armazenamento.

PALAVRAS-CHAVE: qualidade em alimentos, tempo de armazenamento, deterioração, parâmetros sensoriais 


\section{INTRODUCTION}

World aquaculture production continues to grow, according to the latest available statistics collected globally by FAO. Farmed fish contributed to $42.2 \%$ of 158 million tonnes of fish produced by capture fisheries and aquaculture in 2012. The world fish aquaculture production rose by 70.5 million tonnes in 2013 (FAO 2014). In Brazil, there was a significant growth of native fish species production in the last few years. In 2011, 111,084.1 tonnes of Colossoma macropomum were produced (MPA 2011). Native from the Amazon region (including Bolivia, Brazil, Colombia and Venezuela), this species has an efficient performance in intensive farming and reaches high market value (Val et al. 2000).

Tambaqui, or cachama (the common name in Spanish), has a high quality standard due to the relatively short time between harvest, slaughter and the product preservation in aquaculture production, and the possibility to control several parameters during the post-harvest stages. Therefore, it is essential to know the sensory and physicochemical changes that occur during storage of fish in ice for consolidation of fisheries supply chains, in order to avoid losses and increase its commercial potential (Borges et al. 2013). For this purpose, a quality index (QI) scheme or table was developed for tambaqui stored in ice boxes.

The QI is a tool for evaluation of fish freshness, based on the observation of fish quality attributes that receive a score ranging from zero to two or three (where zero is the best and two or three are the worst scores) (Bonilla et al. 2007). It uses a practical qualification system in which the fish is inspected and the corresponding demerit points are recorded. QI is specific for each species, so the European fisheries research institutes developed a strategic alliance called "QIM - EUROFISH" for the globalization of this method, especially with the publication of a manual in several languages containing the fish quality index scheme of various species (Do Amaral and Freitas 2013), especially for marine fish.

There are a few studies with freshwater species. Recently, QI protocols have been developed for pacu, Piaractus mesopotamicus (Holmberg, 1887), with 32 demerit points and a shelf-life of 11 days (Borges et al. 2013), for the hybrid tambacu, Colossoma macropomum $\mathrm{x}$ Piaractus mesopotamicus, with 26 demerit points and shelf-life of 11 days (Borges et al. 2014b), and for the hybrid tambatinga, Colossoma macropomum x Piaractus brachypomus (Cuvier, 1818), with 18 demerit points and a shelf-life of 10 days (Ritter et al. 2016). Tambaqui has a recently developed QI protocol for eviscerated fish, with 34 demerit points and a shelflife of 26 days (Araújo et al. 2016). However, the whole fish (as it is traditionally marketed) has specific characteristics that lead to changes in sensory parameters over time, which require a specific protocol, not yet developed.

Due to the relevance of the QI and the lack of information for farmed whole tambaqui, the evaluation of its meat quality and freshness has become necessary. The aim of this study was to develop and apply the QI scheme for whole ice-stored tambaqui through sensory evaluation, counts of specific spoilage organisms (SSO) and physicochemical evaluations and to determine its shelf- life.

\section{MATERIAL AND METHODS}

A total of 132 tambaquis, Colossoma macropomum, were purchased at the aquaculture station "Ademar Braga" of Departamento Nacional de Obras contra a Seca - DNOCS (National Department of Works Against Drought), in Piripiri, Piauí State, Brazil. The fish were acquired in four batches, one of 36 fish (for protocol development) and three of 32 fish each (for the shelf-life study). All specimens were stored immediately in ice and transported in polystyrene boxes to the laboratory of Food Analysis and Technology, in Parnaíba, Piauí.

For development of the Quality Index (QI) scheme, a pilot experiment was conducted, and for QI application and validation, three experiments (I, II and III) were performed between March and September 2012. Fish were placed inside isothermal boxes with $1 \mathrm{~kg}$ of ice for every $\mathrm{kg}$ of fish (Borges et al. 2013). Temperature was kept close to freezing $\left(0.2 \pm 0.7^{\circ} \mathrm{C}\right)$, and ice was added daily. To ensure the safety of the samples, ice was made with UV-treated water, with sterility proven by water and ice microbiological analysis. The sampled fish had an average weight of $562.45 \pm 134.75 \mathrm{~g}, 496.93 \pm 78.70 \mathrm{~g}$ and $503.14 \pm 48.16 \mathrm{~g}$, respectively, for experiments I, II and III. For each experiment, 20 fish were randomly chosen for sensory analysis, 10 for physical and chemical analysis and 2 for microbiological analysis.

The QI assessment was done as recommended by Sant'Ana et al. (2011). The trained jury consisted of 10 (ten) people, 5 men and 5 women, selected by their experience in sensory analysis of fish. Each member evaluated 36 samples of tambaqui, divided into twelve batches of three fish, in each trial on days $1,3,5,7,9,11,13,15,17,19,21$ and 24, until spoilage defined by the sensory rejection, and when the amounts of volatile nitrogenous compounds and spoilage bacteria count exceeded the limits established by law (30 mg N.100 g-1 and $10^{7}$ UFC.g-1 ${ }^{-1}$, respectively; Brasil 1997; Huss 1995). Thirty six fish were used for development of the Quality Index Scheme, in 12 sessions of one-hour each. The samples were removed from ice 30 minutes before the session, and the observations were conducted under ideal lighting and temperature $\left(20^{\circ} \mathrm{C}\right)$ conditions. After the sessions, the fish that had some injury were discarded to ensure that excessive manipulation did not accelerate deterioration of samples.

The jury described a list of quality attributes for appearance/ texture, eyes, gills, skin, ventral and dorsal muscle and descriptions of how they change with storage time, based on a previous list of descriptors made under the jury leader guidance. After the individual analysis and group discussion, they selected the attributes and the intensity that better characterized the sensory parameters of tambaqui. They allocated the scale points for the 
attributes classification in intensity levels ( 0 for very fresh and 2 for rejection). If there was more than one well-defined intermediate level in the observations, the maximum range was set to 3 . This attributes composed the Quality Index (QI) scheme used for shelf-life determination of whole tambaqui.

For shelf-life study, three experiments were conducted and fishes were evaluated in 1, 3, 5, 8, 10, 12, 15, 17, 19 and 22 days of iced-storage.

Bacteriological analysis was done as recommended by Sant'Ana et al. (2011) adapted from Cousin et al. (2001). Individual areas of $14.0 \mathrm{~cm}^{2}(4.0 \times 3.5 \mathrm{~cm})$ of the skin (both sides of two fish) were swabbed with sterile cotton swabs, in duplicate. The swabs were transferred to tubes containing $5.0 \mathrm{ml}$ of $0.85 \% \mathrm{NaCl}$ solution. Appropriate series of decimal dilutions were performed, and surface inoculation was accomplished using the $20 \mu \mathrm{l}$ drop method in Pseudomonas Agar (OXOID, Basingstoke, Hampshire, UK) to detect Pseudomonas; Nutrient Agar (OXOID, Basingstoke, Hampshire, UK) to count psychrophilic bacteria; MacConkey Agar (OXOID, Basingstoke, Hampshire, UK) for the Enterobacteriaceae counting; Plate Count Agar (PCA) (HIMEDIA, Mumbai, India) for mesophilic and heterotrophic aerobic bacteria; and Iron Agar for bacteria producing $\mathrm{H}_{2} \mathrm{~S}$ (OXOID, Basingstoke, Hampshire, UK). The plates containing the Pseudomonas Agar, Nutrient Agar and Iron Agar were incubated at $20^{\circ} \mathrm{C}$ for 24 to 48 hours; MacConkey Agar was incubated at $35^{\circ} \mathrm{C}$ for 24 to 48 hours, and PCA was incubated at $35^{\circ} \mathrm{C}$ for 24 to 48 hours and also incubated at $5^{\circ} \mathrm{C}$ for seven days (Table 1). Counts were performed in duplicate and expressed as logarithm of $\mathrm{cfu}\left(\mathrm{cm}^{2}\right)^{-1}$.

Ten samples were evaluated on day 1, 4, 8, 12, 15, 19 and 22. The $\mathrm{pH}$ was determined using a digital $\mathrm{pH}$ meter (TESTO, model 205, Campinas, São Paulo, Brazil) equipped with a glass electrode (calibrated at $\mathrm{pH}$ four and seven), which was inserted into the fish muscle. Total volatile base nitrogen (TVB-N) was measured by protein precipitation with trichloroacetic acid (TCA, 7.5\%, Synth ${ }^{\circledR}$, Diadema, São Paulo, Brazil) and by evaluation of the TCA extract using the Micro Kjeldahl procedure according to an adapted method from Brasil (1981). The proximate composition was determined according to AOAC (2005). Moisture content was determined by the sample $(2.0 \mathrm{~g})$ weight difference before and after heating in an oven (QUIMIS, São Paulo, São Paulo, Brazil) for 24 h at 105 ${ }^{\circ} \mathrm{C}$. The total level of nitrogen was determined by the Kjeldahl procedure, and protein levels were estimated using a conversion factor of 6.25. Lipids were determined by extraction with petroleum ether in a Soxhlet apparatus (SOLAB, Campinas, São Paulo, Brazil). Three determinations from the same sample were performed for all analyses.

The sensorial analysis data were evaluated for normality through the Shapiro-Wilk test (Zar 2010). Linear regression and Pearson's correlation between the QI score versus iced storage were measured using the OriginPro 8.1 software. Additionally, a partial least squares (PLS) regression was used to determine the uncertainty associated with QI prediction and the sensory attributes relevant for its development (Borges et al. 2014a), using the program XLSTAT for Windows version 2012.5 (Adinsoft, Paris, France).

\section{RESULTS}

The resulting QI scheme had four quality attributes (general appearance, gills, eyes and texture) divided into 12 parameters (Table 2). According to the tambaqui sensory characteristics, parameters were assigned a score ranging from 0 to 2 or 0 to 3 . Up to 2 demerit points to "scales", "general appearance" and "fish odor", 2 points for "color", "odor", "form" and "mucus" of gills, 3 points for "pupil transparency" and "shape of eyes", 2 points for "back elasticity" and 3 for "ventral elasticity" (Figure 1).

The scores given for all the quality attributes are summarized by the Quality Index (Figure. 2), which increases linearly with the storage time in ice. However, some attributes did not show the highest score during the shelf-life study. That's because some sensory characteristics showed a slow rise while other parameters accused higher values which established the rejection point. The "odor" received lower average scores, with a demerit score of 0.03 (at day 1) and 1.05 (at day 22) when the jury already classified tambaqui as unfit for consumption. On the contrary, the attributes related to the eyes and gills presented the highest loss of freshness. At day 5, the average score of gills had passed one (1.0) point. Also, the attributes "transparency", "pupil" and "eye shape" scored $1.08,1.38$ and 1.33 points, respectively. These last attributes were close to 3 points at day 22 (rejection point) (Figure 1).

The gills (color and odor) changed faster, varying from shine red to dark red and from mild /delicate odor of seaweed to sweetish acrid on day five (5) (Table 2). On the $19^{\text {th }}$ day, the gills showed brown color and bloody mucus. The odor, considered

Table 1. Description of microbiological media, temperature and time of incubation used in the study of shelf-life for whole tambaqui, Colossoma macropomum storage in ice.

\begin{tabular}{|c|c|c|}
\hline Media & Bacteria & Temperature/ Incubation time \\
\hline Pseudomonas Agar & Pseudomonas & $20^{\circ} \mathrm{C} / 24$ to 48 hours \\
\hline Nutrient Agar & Psychrophilic bacteria & $20^{\circ} \mathrm{C} / 24$ to 48 hours \\
\hline \multirow{2}{*}{ Plate Count Agar (PCA) } & Mesophilic aerobic bacteria & $35^{\circ} \mathrm{C} / 24$ to 48 hours \\
\hline & Psychrotrophic aerobic bacteria & $5^{\circ} \mathrm{C} / 7$ days \\
\hline Iron Agar & Bacteria producing $\mathrm{H}_{2} \mathrm{~S}$ & $20^{\circ} \mathrm{C} / 24$ to 48 hours \\
\hline
\end{tabular}


Table 2. Ql scheme for whole tambaqui, Colossoma macropomum, ice-storage assessment

\begin{tabular}{|c|c|c|c|}
\hline Qualities/ attributes & & Descriptors & Score \\
\hline \multirow{10}{*}{ General appearance } & \multirow{4}{*}{ Superficial aspects } & Bright colors, golden on dorsal region and black on ventral one & 0 \\
\hline & & Slight loss of color/ opaque colors & 1 \\
\hline & & Marked loss of staining & 2 \\
\hline & & Green coloration on the white sections by bacterial colonization & 3 \\
\hline & \multirow{3}{*}{ Odor } & Fresh fish smell / suitable odor & 0 \\
\hline & & Sweetish/acrid & 1 \\
\hline & & Rancid & 2 \\
\hline & \multirow{3}{*}{ Scales } & Firm and well attached & 0 \\
\hline & & Few attached / dropping scales & 1 \\
\hline & & An easy dropping & 2 \\
\hline \multirow{12}{*}{ Eyes } & \multirow{4}{*}{ Eyeball } & Transparent/ bright & 0 \\
\hline & & Lightly opaque & 1 \\
\hline & & Whitish & 2 \\
\hline & & Opaque/ reddish & 3 \\
\hline & \multirow{4}{*}{ Pupil } & Dark/rounded/well defined & 0 \\
\hline & & Lightly opaque/ rounded/ well defined & 1 \\
\hline & & Loss of design/foggy/opaque/unfit & 2 \\
\hline & & Opaque/ unfit & 3 \\
\hline & \multirow{4}{*}{ Shape } & Protuberant/occupying all eye socket/lightly convex & 0 \\
\hline & & slightly convex & 1 \\
\hline & & Concave/partially occupying the eye orbit & 2 \\
\hline & & Concave/ out of the eye orbit & 3 \\
\hline \multirow{12}{*}{ Gills } & \multirow{3}{*}{ Color } & Vibrant red/bright & 0 \\
\hline & & Dark red/washed-out parts & 1 \\
\hline & & Brown/ colorless & 2 \\
\hline & \multirow{3}{*}{ Odor } & Algae & 0 \\
\hline & & acrid/metallic/ sweetish & 1 \\
\hline & & Lightly rancid & 2 \\
\hline & \multirow{3}{*}{ Shape } & Uniform & 0 \\
\hline & & Slightly misshapen & 1 \\
\hline & & Misshapen / shredded & 2 \\
\hline & \multirow{3}{*}{ Mucus } & Absent/reddish & 0 \\
\hline & & Yellowish & 1 \\
\hline & & With blood/ brown coloration/thick & 2 \\
\hline \multirow{7}{*}{ Texture } & \multirow{4}{*}{ Ventral elasticity } & Rigid & 0 \\
\hline & & Good elasticity & 1 \\
\hline & & Lightly firm & 2 \\
\hline & & Loss of elasticity/soft & 3 \\
\hline & \multirow{3}{*}{ Dorsal elasticity } & Good elasticity & 0 \\
\hline & & Lightly firm & 1 \\
\hline & & Loss of elasticity/soft & 2 \\
\hline Quality index (QI) & & & $0-29$ \\
\hline
\end{tabular}




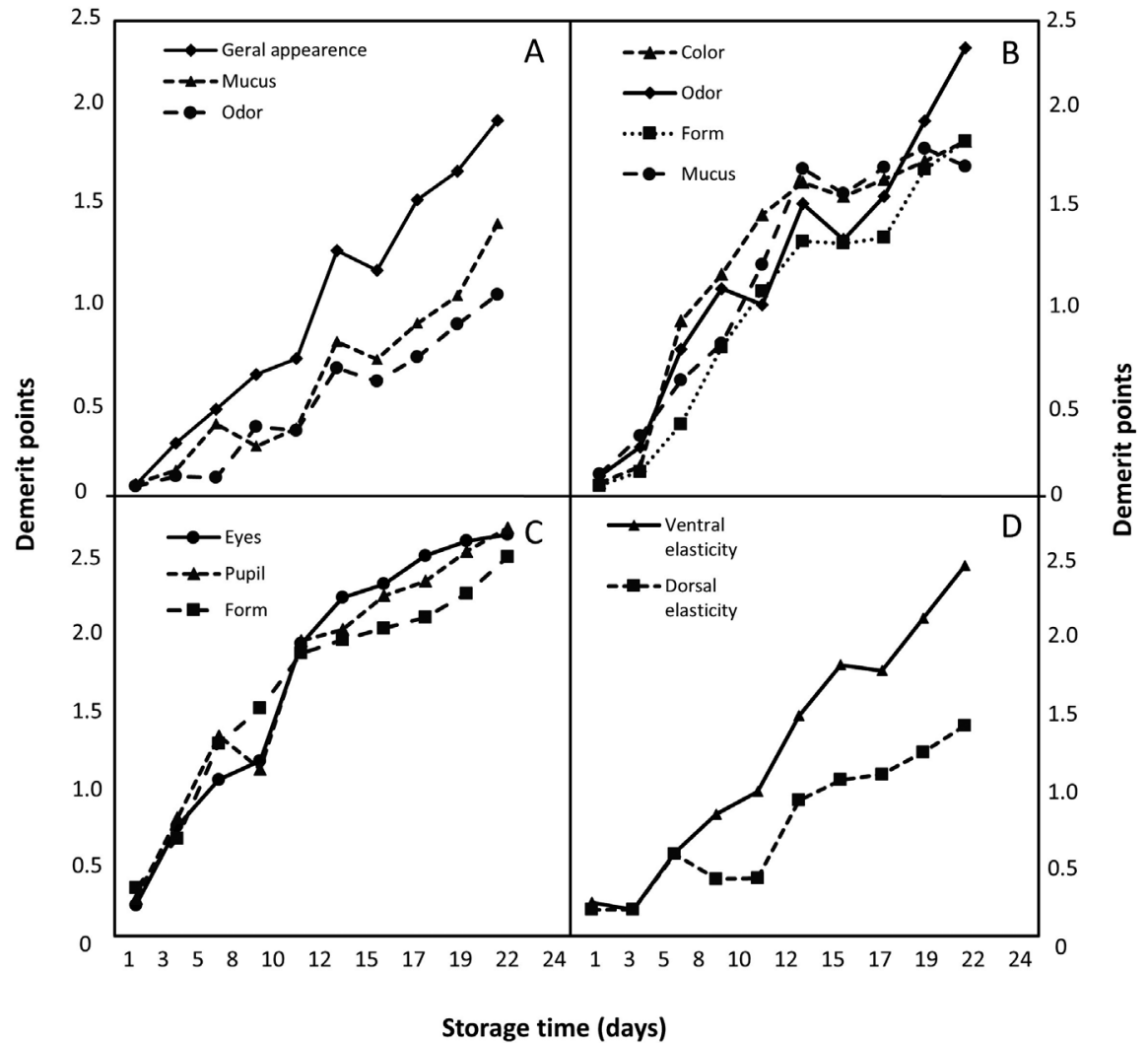

Figure 1. The average demerit scores given on different storage days for each quality attribute of ice-stored whole tambaqui, Colossoma macropomum: (A) Appearance; (B) Gills; (C) eyes; (D) texture.

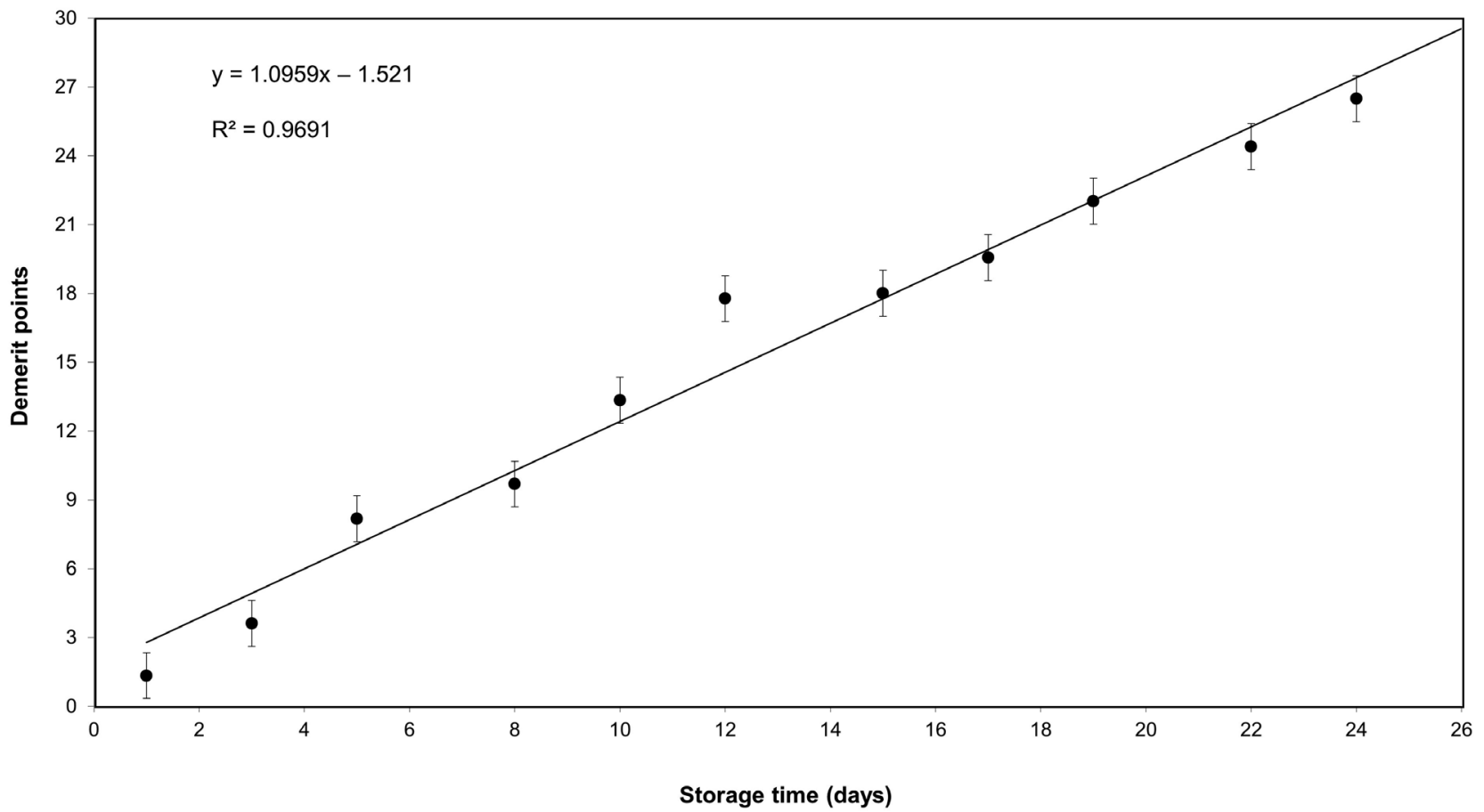

Figure 2. Linear correlation between Ql and the 29 demerit points for ice-stored whole tambaqui, Colossoma macropomum. Bars represent the daily standard deviation. 
the most important attribute in fish sensory analysis, changed gradually throughout storage time, and rancid smell only had higher demerit points on the 22nd day (Figure 1).

The elasticity losses observed by the jury in tambaqui muscle could be related to the reduction of $21.68 \%$ in muscle protein from day 1 to 9 , and $1.30 \%$ from day 9 to 18 (Table 3 ).

At rejection ( $22^{\text {nd }}$ day), the fish received 26 demerit points, $86 \%$ of the QI maximum score (Figure 2). At this point of evaluation, gills presented rancid odor, eyes were opaque and red, and texture was flaccid from lost elasticity (Figure 1), which led the jury to reject the samples for consumption.

The Quality Index is based on a statistical model that correlates sensory analysis with storage time. The correlation between tambaqui QI parameters and predicted values can be observed in the partial least squares (PLS) regression, which had a strong correlation coefficient $\left(\mathrm{R}^{2}=0.981\right)$ between demerit points and the prediction model (Figure 3). The contribution of each parameter is demonstrated on Variable
Importance in the Projection (VIP) (Figure 4), which showed positive and negative importance in its development through standardized coefficients. All the QI attributes were considered significant by the model (supporting the jury's observations), even gill mucus and color, which showed lower significance in the model. The standard deviation estimated for the QI was 1.099 days according to the PLS regression with the 95\% regression confidence limits (Figure 3), while the standard error of performance (SEP), used to assess the precision of the QI prediction in days, was 0.845 , meaning that shelf-life may vary by one or more days.

TVB-N values increased from 15.23 to $23.17 \mathrm{mg} \mathrm{N} 100$ $\mathrm{g}^{-1}$ from day 1 to 22 , while $\mathrm{pH}$ increased from 6.52 to 6.71 in the same period (Figure 5). The mesophilic, psychrophilic and psychotropic bacteria remained under $10^{6} \mathrm{CFU}$ during the study period, and $\mathrm{H}_{2} \mathrm{~S}$ producing bacteria showed reduced growth rate throughout the experiment (Figure 6).

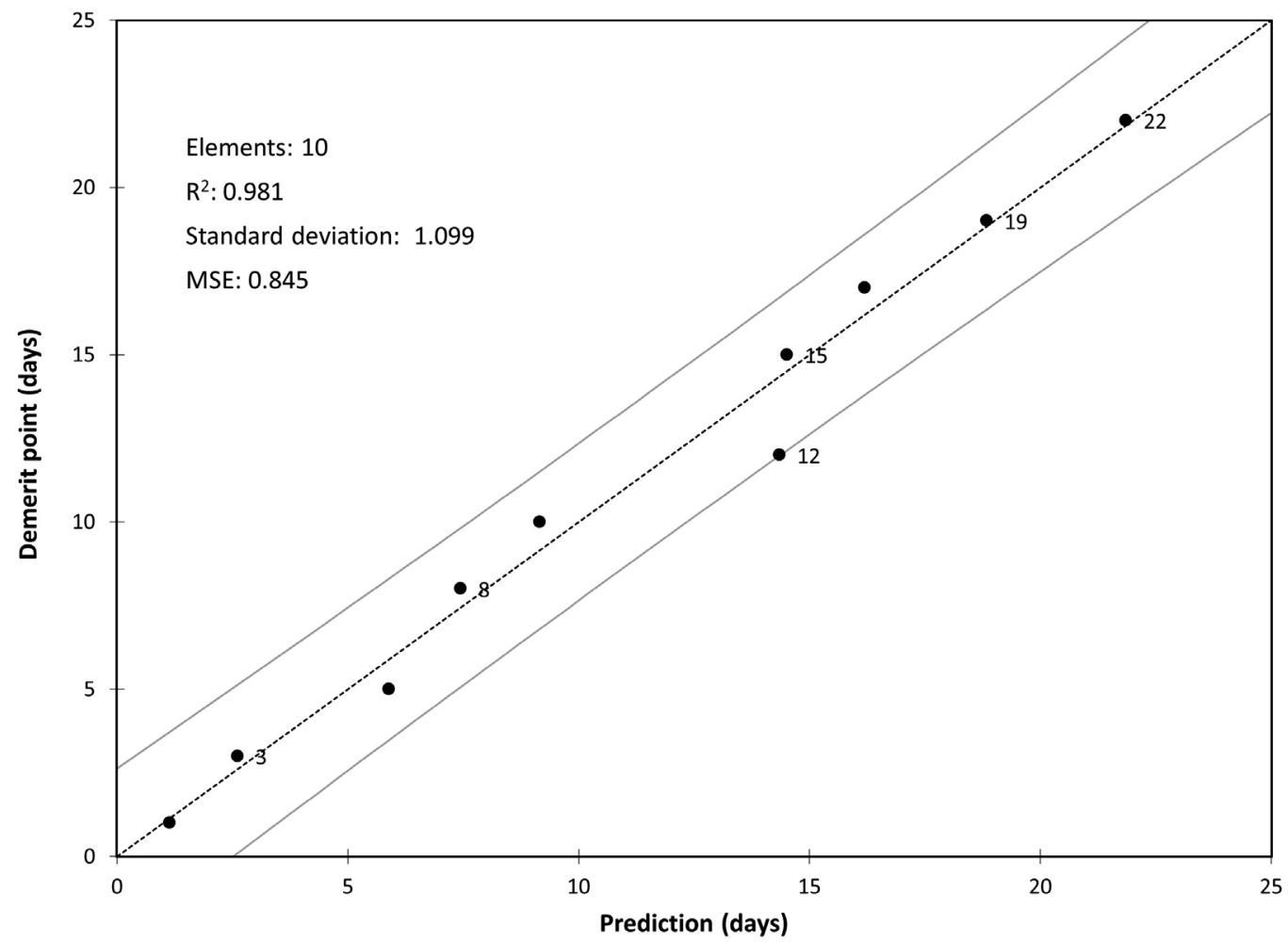

Figure 3. Partial Least Square (PLS) regression of QI with 29 demerit points versus the predicted scores. Traced lines represent $95 \%$ regression confidence limits

Table 3. Proximate composition (moisture, protein and lipids) of whole ice-stored tambaqui, Colossoma macropomum, on day 1,9 and 18 of its shelf life.

\begin{tabular}{lllll}
\hline Day & $1^{\circ}$ & $9^{\circ}$ & $18^{\circ}$ & CV (\%) \\
\hline Moisture (\%) & $79.90^{\mathrm{a}}$ & $81.26^{\mathrm{b}}$ & $81.56^{\mathrm{b}}$ & 0.79 \\
Crude Protein (\%) & $22.37^{\mathrm{a}}$ & $17.56^{\mathrm{b}}$ & $17.52^{\mathrm{b}}$ & 9.62 \\
Lipids (\%) & $0.48^{\mathrm{a}}$ & $0.37^{\mathrm{a}}$ & $0.51^{\mathrm{a}}$ & 61.86 \\
\hline
\end{tabular}

Means on the same line followed by different letters are significantly different $(p<0.05), n=12$. 


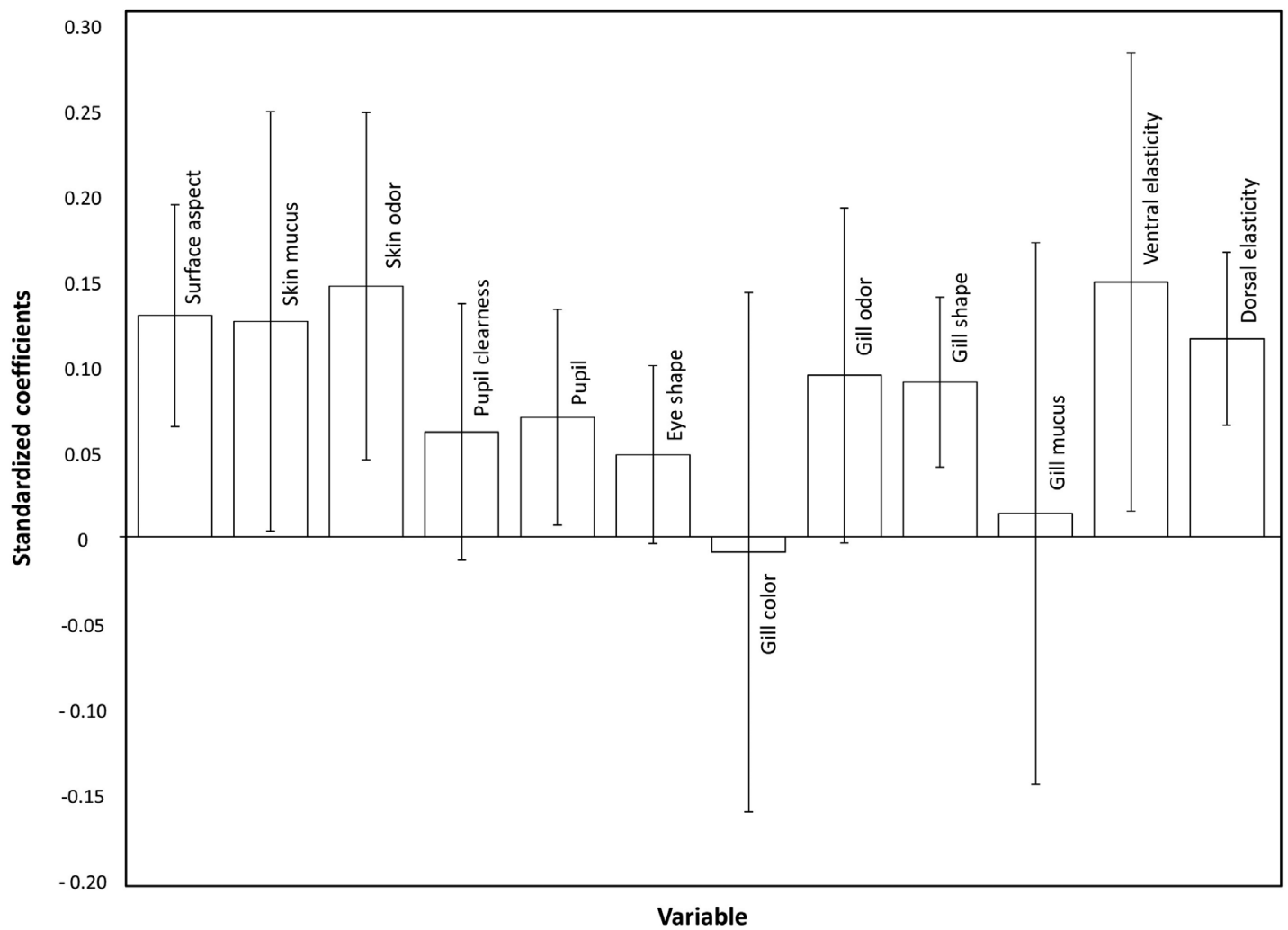

Figure 4. The variable importance in the projection (VIP) for QI parameters developed for ice-stored whole tambaqui, Colossoma macropomum, with a 95\% regression confidence.

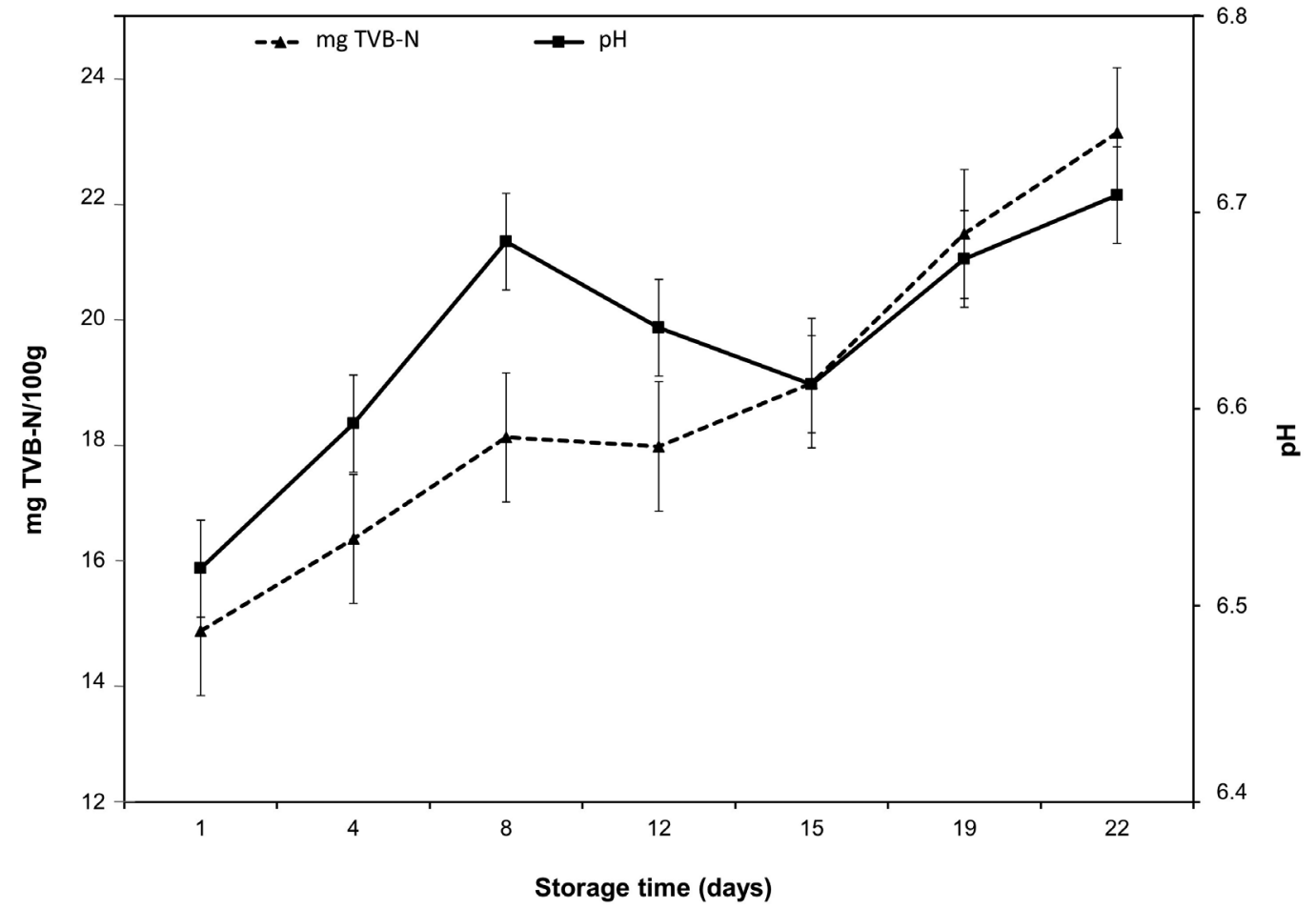

Figure 5. Variation of $\mathrm{pH}$ and TVB-N (mg $100 \mathrm{~g}^{-1}$ ) for whole tambaqui, Colossoma macropomum stored in ice. 


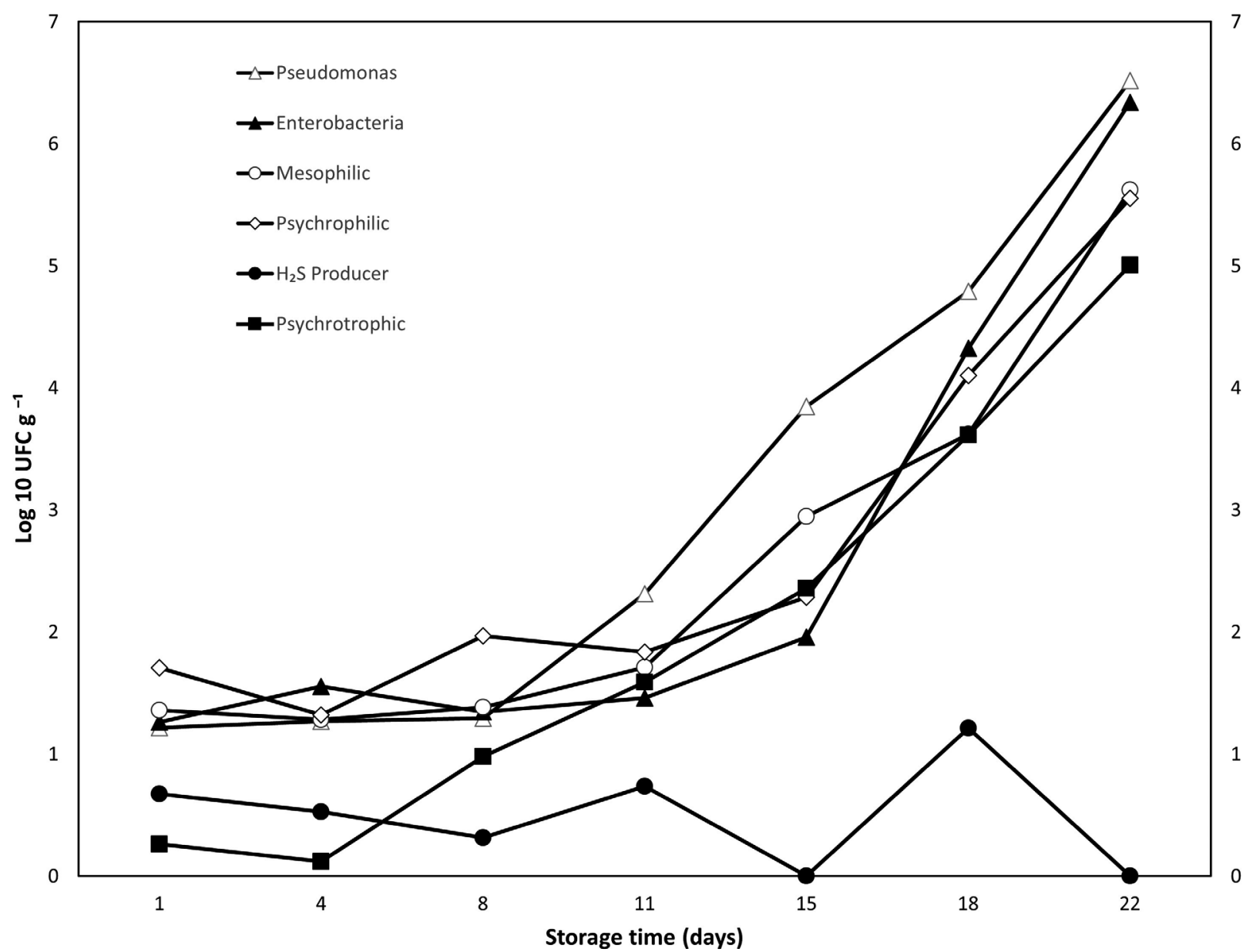

Figure 6. Mean counts of bacteria Pseudomonas, Enterobacteriaceae, $\mathrm{H}_{2} \mathrm{~S}$ Producers, mesophilic, and psychrotrophic (log $\mathrm{CFU}^{-1}$ ), during the period in ice storage (days) of whole tambaqui, Colossoma macropomum.

\section{DISCUSSION}

The QI scheme in this study had four quality attributes divided into 12 parameters and 29 demerit points, which was almost $20 \%$ lower than that developed for eviscerated tambaqui (36 demerit points) (Araujo et al. 2016). However, similar results were obtained for pacu, Piaractus mesopotamicus, with 16 parameters and 32 demerit points (Borges et al. 2013) and for the hybrid tambacu (C. macropomum and P. mesopotamicus), with 11 parameters and 26 demerit points (Borges et al. 2014a). That similarity is due to pacu and tambacu belonging to the Characidae family (Ritter et al. 2016). For species such as seabream, Sparus aurata Linnaeus, a maximum score with only 15 demerit points was obtained (Simat et al. 2012). The different results show the importance of QI to evaluate fish quality, because it is species-specific and considers the different perceptions of the jury (Lanzarin et al. 2016).
The Quality Index parameters increased linearly with the storage time. Odor and general appearance increased slowly, while the attributes related to the eyes ("transparency", "pupil" and "eye shape") and gills ("color" and "odor") presented the highest loss of freshness. These results agree with Almeida $e t$ al. (2006) who observed that the first changes in tambaqui stored in ice included a larger amount of mucus on the gills and a smooth deformation of the eyes caused by friction with the ice. The autolytic reactions caused by the increased storage time, combined with the water absorption from the melting ice, make the observation of the eyes and evaluation of their quality attributes more difficult and confusing to the jury (Ritter et al. 2016). Similarly, the eyes of Amazonian pintados, Pseudoplatystoma fasciatum (Linnaeus, 1766) x Leiarius marmoratus (Gill, 1870) remained only slightly opaque until the 16th storage day, then turning opaque, with a progressive increase in the demerit points with increasing storage time (Lanzarin et al. 2016). In the piramutaba or Laulao catfish, 
Branchyplatystoma vaillant (Valenciennes, 1840), the opacity of pupil and cornea, including the eye flatness, were reported on the tenth storage day (Marinho et al. 2014). A similar evolution of the eye attributes was observed for the Atlantic salmon, Salmo salar L. (Sveinsdóttir et al.2002) and the croaker, Micropogonias furnieri (Desmarest, 1823) (Teixeira et al. 2009).

The changes of gill color and odor seems to be characteristic for the Characidae fish, since in the hybrid tambatinga, the color of gills was also initially red blood, becoming brownish red and reaching a brownish color throughout the ice storage (Ritter et al. 2016). Off odor is the primary cause of acceptability reduction of fish by consumers and it is due to large amounts of non-protein nitrogen, high content of fat and autolytic enzymes in the fish tissues (Huss 1995).

Because of these rapid changes of sensorial parameters, the total of demerit points did not reach the maximum score during the shelf-life study. The QI for quality evaluation of cod, Gadus morhua (Linnaeus, 1758), stored on ice at $0 \pm 1{ }^{\circ} \mathrm{C}$ during 14 days, reached 18 points as maximum score, which resulted in a shelf-life of eight days (Bonilla et al. 2007). The QI for pacu reached a total of 18 demerit points $(56.2 \%$ of the maximum score) (Borges et al. 2013).

Our QI for whole ice-storaged tambaqui presented statistically sound parameter values. The variable importance in the projection (VIP) shows relevance when attributes are $\geq 1.0$ (Donadoni et al. 2012). Therefore, skin mucus and odor, as well as general appearance and ventral elasticity had the highest importance for tambaqui QI. For eviscerated tambaqui all the quality attributes, except for blood press eyes, were relevant for the QI scheme (Araujo et al. 2016).

The values determined for standard deviation (1.099 days) and standard error of performance (0.845) were within the estimated range for others species. SEP was 1.184 for pacu (Borges et al. 2013), 1.057 for tambacu (Borges et al. 2014b) and 2.9 for eviscerated tambaqui (Araújo et al. 2016), usually at intervals of up to 1 and 5 days. Cyprian et al. (2008) developed a QI for arctic char, Salvelinus alpinus (Linnaeus), a freshwater fish, with results similar to those found in the present study: quality attributes and storage time had a high linear correlation and the SEP was only 1.48 (one day).

The TVB-N values for whole tambaqui on ice over 22 days complied with the Brazilian legislation (maximum of $30 \mathrm{mg}$ N.100 g ${ }^{-1}$; Brasil 1997). Changes in TVB-N values found for Amazonian pintado were within 9.45 (on the first day of ice storage) and $13.37 \mathrm{~N} .100 \mathrm{~g}^{-1}$, with a significant linear increase of $41.48 \%$ after 28 days of ice storage ( $<<0.01)$ (Lanzarin $e t$ al. 2016). The perception of odor in fish can be related to the gradual increase of TVB-N caused by bacterial activity (Huss 1995). The metabolites produced by mesophilic bacteria were probably responsible for the decrease in the sensory odor quality of tambacu (Borges et al. 2014b) that was also observed for tambaqui in this study.
The increase in $\mathrm{pH}$ measured throughout the storage of whole tambaqui can be explained by post mortem biochemical reactions in fish muscle. After slaughter, a small decrease in $\mathrm{pH}$ occurs as a result of disruption of the oxygen supply to the muscle tissue, where muscle glycogen becomes anaerobic and converted to lactic acid by glycolysis (Mendes et al. 2017). The gradual increase in $\mathrm{pH}$ values after harvesting also reflected the production of alkaline bacterial metabolites in spoiling fish and coincided with the increase in total volatile basic nitrogen (Abbas et al. 2008). Similar results were reported for tambatinga, whith a linear increase in $\mathrm{pH}$ from 6.25 to 6.74 at day 28 (Ritter et al. 2016), and for eviscerated tambaqui, whith an increase in $\mathrm{pH}$ from 6.01 (first day) to 6.45 at the end of shelf-life (22 $2^{\text {th }}$ day) (Araujo et al. 2016). The Industrial Inspection and Sanitary Regulation of Animal Products RIISPOA (Brasil 2001) establishes that the maximum $\mathrm{pH}$ for fresh fish should be below 6.8 in external meat and 6.5 in the inner flesh (Cartonilho and Jesus 2011). For marine fish, $\mathrm{pH}$ values in the muscle can be very low (approximately 5.50) during the beginning of storage (Shiau 2007) and increase with time.

The $\mathrm{pH}$ and the microbial development and activity are proportionally related. Increased $\mathrm{pH}$ leads to greater microorganism growth (Simat et al. 2012). In the present study, $\mathrm{pH}$ increased from the 12th day on concomitantly with bacteria counting (mesophilic, psychotropic, psychrophilic and Pseudomonas). Microorganisms are very important for the evaluation of fresh fish, because many of the volatile compounds are produced from the metabolism of specific spoilage organisms (SSO), including volatile sulfur compounds typical of the deterioration of fish (Huss 1997) and loss of muscle elasticity (Ando et al. 1999).

In this study, Pseudomonas and Enterobacteria counting showed an increase close to the limit recommended by the World Health Organization (WHO) $\left(10^{7}\right.$ Colony Forming Units - CFU). Even under lower temperature, a strong growth of heterotrophic aerobic psychrotrophic bacteria was observed in tambatinga (Ritter et al. 2016). This growth may also be due to the use of gutted tambatinga, which can favor the entry of microorganisms into the muscle, which then stimulate the spoilage process. The samples analyzed in this study can be considered satisfactory in relation to hygiene of storage conditions, since they did not exceed the acceptable limits until the $22^{\text {nd }}$ day of storage (Huss 1997).

All the observation points were very close to the abscissa in the regression line, except for day 12 , exactly when the bacteria count increased. Judges were in better agreement when evaluating the fresh fish using the QI protocol, as compared to spoilage fish (Sveinsdóttir et al. 2002). This was observed in the shelf-life study: the judges sensed the sensory changes caused by bacteria growth. These differences demonstrate that QI is important for fish quality evaluation, but the most appropriate 
assessment should include a set of methods (microbiological, physico-chemical and sensory analysis) in order to achieve more concise and relevant results (Ritter et al. 2016).

The elasticity losses observed by the jury in tambaqui muscle and the reduction in muscle protein were also observed in super chilled salmon fillets, which showed a loss of $16 \%$ up to the $7^{\text {th }}$ storage day, and a $2 \%$ reduction from the $7^{\text {th }}$ to $14^{\text {th }}$ day (Kaale and Eikevik 2016). The biological proteins decrease because of reactions with the amine groups of lysine, the oxidation of methionine, and other amino acids changes (Tironi et al. 2009), and it is also related to texture modifications by crosslinking polypeptide chains (Aubourg 1999). Thus, proteases and microorganisms cause natural degradation of myofibrillar proteins and collagen (Chéret et al. 2006) and explain how the muscle becomes weak during ice storage (Ando et al. 1999). The collagen degradation of muscle fibers of cobia (Rachycentron canadum) was as certained by sensory and histological analyses (Fogaça et al. 2016). After death, collagen was degraded through a progressive breakdown of the collagen junctions between the myocommata and the muscle fibers (Delbarre-Ladrat $e t$ al. 2006) caused by microbial and enzyme reactions that are promoted by $\mathrm{pH}$ increases (Huss 1997).

\section{CONCLUSIONS}

The IQ protocol developed for whole tambaqui stored in ice was efficient and reliable for sensory, chemical and microbiological changes. Under the experimental conditions of this study, the analysis of TVB-N cannot be considered a good index for evaluating the loss of freshness of tambaqui stored in ice. Therefore, it is suggested that whole tambaqui Colossoma macropomum stored in ice has a shelf-life of 22 days.

\section{ACKNOWLEDGMENTS}

The authors are thankful to CAPES (Coordenaçấo de Aperfeiçoamento de Pessoal de Nível Superior - grant 421/2010), FAPEMA (Fundação de Amparo à Pesquisa e ao Desenvolvimento Científico e Tecnológico do Maranhão) for the financial support, CODEVASF (Companhia de Desenvolvimento do Vale do Rio São Francisco e Baixo Parnaíba) for the use of their equipment, and to DNOCS (Departamento Nacional de Obras contra a Seca) for donating the fish samples.

\section{REFERENCES}

Abbas, K.A.; Mohamed, A.; Jamilah, B.; Ebrahimian, M. 2008. A Review on Correlations between Fish Freshness and $\mathrm{pH}$ during Cold Storage. American Journal of Biochemistry and Biotechnology, 4: 416-421.

Almeida, N.M.; Batista, G.M.; Kodaira, M.; Lessi, E. 2006. Alterações post-mortem em tambaqui (Colossoma macropomum) conservados em gelo. Ciência Rural, 36: 1288-1293.
Ando, M.; Nishiyabu, A.; Tsukamasa, Y. 1999. Post-mortem softening of fish muscle during chilled storage as affected by bleeding. Journal of Food Science, 64: 423-428.

AOAC. 2005. Official methods of analysis. $18^{\text {th }}$ ed. Association of Analytical Chemists, Gaithersburg, 510p.

Araújo, W.S.C.; De Lima, C.L.S.; Joele, P.; Lourenço, L.D.F.H. 2016. Development and Application of the Quality Index Method (QIM) for farmed Tambaqui (Colossoma macropomum) stored under refrigeration. Journal of Food Safety, 37: 1-9.

Aubourg, S.P. 1999. Recent advances in assessment of marine lipid oxidation by using fluorescence. Journal American Oil Chemistry Society, 76: 409-419.

Bonilla, A.C.; Sveinsdóttir, K.; Martinsdóttir, E. 2007. Development of quality Index Method (QIM) scheme for fresh cod (Gadus morhua) fillets and application in shelf life study. Food Control, 18: 352-358.

Borges, A.; Conte-Junior, C.A.; Franco, R.M.; Freitas, M.Q. 2013. Quality Index Method (QIM) developed for pacu Piaractus mesopotamicus and determination of its shelf life. Food Research International, 54: 311-317.

Borges, A.; Conte-Junior, C. A.; Franco, R. M.; Mársico, E. T.; Freitas, M. Q. 2014a. Quality parameters of pacu (Piaractus mesopotamicus) and tambaqui (Colossoma macropomum) gutted and stored on ice for different periods. International Food Research Journal, 21: 589-596.

Borges, A.; Conte-Júnior, C.A.; Franco, R.M.; Marsico, E.T.; Freitas, M.Q. 2014b. Quality Index Method (QIM) for the hybrid tambacu (Colossoma macropomum x Piaractus mesopotamicus) and the correlation among its quality parameters. LWT - Food Science and Technology, 56: 432-439.

Brasil. 1981. Métodos analíticos oficiais físico-químicos para controle de pescado e seus derivados. MAPA, Brasília, 30p.

Brasil. 1997. Regulamento Técnico de Identidade e Qualidade de Peixe Fresco (Inteiro e Eviscerado). MAPA, Brasília, 45p.

Brasil. 2001. Regulamento da Inspeção 69 Industrial e Sanitária de Produtos de Origem Animal (RIISPOA). MAPA, Brasília, 241p.

Cartonilho, M.M.; Jesus, R.S. 2011. Qualidade de cortes congelados de tambaqui cultivado. Pesquisa Agropecuária Brasileira, 46: 344-350.

Chéret, R.; Hernández-Andrés, A.; Delbarre-Ladrat, C.; De Lamballerie, M.; Verrez-Bagnis, V. 2006. Proteins and proteolytic activity changes during refrigerated storage in sea bass (Dicentrarchus labrax L.) muscle after high-pressure treatment. European Food Research and Technology, 222: 527-535.

Cousin, M.A.; Jay, J.M.; Vasavada, P.C. 2001. Psychrotrophic microorganisms. In: Vanderzand, C.; Splittstoesse, D.F. (Ed.). Compendium of Methods for the Microbiological Examination of Foods. American Public Health Association, Washington, DC, p.153-168.

Cyprian, O.O.; Sveinsdóttir, K.; Magnússon, H.; Martinsdóttir, E. 2008. Application of Quality Index Method (QIM) scheme and effects of short-time temperature abuse in shelf life study of fresh water artic char (Salvelinu alpinus). Journal Aquatic Food Production Technology, 17: 303-321. 
Delbarre-Ladrat, C.; Chéret, R.; Taylor, R.; Verrez-Bagnis, V. 2006. Trends in postmortem aging in fish: understanding of proteolysis and disorganization of the myofibrillar structure. Critical Reviews in Food Science and Nutrition, 46: 409-421.

Do Amaral, G.V.; Freitas, D.G.C. 2013. Método do índice de qualidade na determinação do frescor de peixes. Ciência Rural, 43: 2093-2100.

Donadoni, G.; Fumi, M.D.; Vanoni, L.; Porretta, S. 2012. Hedonic responses to cheese in preschoolers. Journal of Sensory Studies, 27: 176-187.

FAO. 2014. Global Aquaculture Production (http://www.fao.org/ fishery/statistics/global-aquaculture-production/en). Accessed on $08 / 06 / 2014$.

Fogaça, F.H.S.; Gonzaga Junior, M.A.; Vieira, S.G.A.; Araujo, T.D.S.; Farias, E.A.; Ferreira-Bravo, I.A.; Calvet, R.M.; Pereira, A.M.L.; Prentice-Hernández, C. 2016. Appraising the Shelf Life of Farmed Cobia, Rachycentron canadum, by Application of a Quality Index Method. Journal of The Aquaculture Society, 48: 70-82.

Huss, H.H. 1995. Quality Changes and Shelf Life of Chilled Fish in Quality and quality changes in fresh fish. In: Huss, H.H. (Ed.). Fisheries Technical Paper 348. FAO, Roma, Italy, 36p.

Huss, H.H. 1997. Deterioration in Assurance of seafood quality. In: Huss, H.H. (Ed.). Fisheries Technical Paper 334. FAO, Roma, Italy, 45p.

Kaale, L.D.; Eikevik, T.M. 2016. Changes of proteins during superchilled storage of Atlantic salmon muscle (Salmo salar). Journal of Food Science and Technology, 53: 441-450.

Lanzarin, M.; Ritter, D.O.; Novaes, S.F.; Monteiro, M.L.G.; Almeida-Filho, E.S.; Marsico, E.T.; Franco, R.M.; Conte-Junior, C.A.; Freitas, M.Q. 2016. Quality Index Method (QIM) for ice stored gutted Amazonian Pintado (Pseudoplatystoma fasciatum $x$ Leiarius marmoratus) and estimation of shelf life. $L W T$ - Food

MPA. 2011. Boletim estatístico da pesca e aquicultura, Brasil (http:// www.mpa.gov.br/images/Docs/Informacoes_e_Estatisticas/ Boletim\%20Estat\%C3\%ADstico\%20MPA\%202010.pdf). Accessed on $07 / 08 / 2012$.

Mendes, J.M.; Dairiki, J.K.; Inoue, L.A.K.A.; Jesus, R.S. 2017. Advantages of recovery from pre-slaughter stress in tambaqui Colossoma macropomum (Cuvier 1816) agroindustry in the Amazon. Food Science and Technology, 37: 383-388.

Ritter, D.O.; Lanzarin, M.; Novaes, S.F.; Monteiro, M.L.G.; Almeida-Filho, E.S.; Marsico, E.T.; Franco, R.M.; Conte-Junior,
C.A.; Freitas, M.Q. 2016. Quality Index Method (QIM) for gutted ice-stored hybrid tambatinga (Colossoma macropomum $\mathrm{x}$ Piaractus brachypomus) and study of shelf life. LWT - Food Science and Technology, 67: 55-61.

Sant'Ana, L.S.; Soares, S.; Vaz-Pires, P. 2011. Development of a quality index method (QIM) sensory scheme and study of shelf-life of ice-stored blackspot seabream (Pagellus bogaraveo). LWT-Food Science and Technology, 44: 2253-2259.

Sveinsdóttir, K.; Martinsdóttir, E.; Hyldig, G.; Jorgensen, B.; Kristbergsson, K. 2002. Application of quality index method (QIM) scheme in shelf-life study of farmed Atlantic salmon (Salmo salar). Journal of Food Science, 67: 1570-1579.

Shiau, C.Y. 2007. Biochemical composition and utilization of cultured cobia (Rachycentron canadum). In: Liao, I.C.; Leano, E.M. (Ed.). Cobia aquaculture: Research, developments and commercial production. Asian Fisheries Society, Manila, Philippines, p.147-156.

Šimat, V.; Bogdanović, T.; Krželj, M.; Soldo A.; Maršić-Lučić, J. 2012. Differences in chemical, physical and sensory properties during shelf life assessment of wild and farmed gilthead sea bream (Sparus aurata, L.). Journal of Applied Ichthyology, 28: 95-101.

Teixeira, M.S.; Borges, A.; Franco, R.M.; Clemente, S.C.S.; Freitas, M.Q. 2009. Método de Índice de Qualidade (MIQ): protocolo sensorial para corvina (Micropogonias furnieri). Revista Brasileira Ciência Veterinária, 16: 83-88.

Tironi, V.; Toma’s, M.; Anón, M. 2009. Lipid and protein changes in chilled sea salmon (Pseudopercis semifasciata): effect of previous rosemary extract (Rossmarinus officinalis L.) application. International Journal of Food Science and Technology, 44: 1254-1262.

Val, A.L.; Rolim, P.R.; Tabelo, H. 2000. Situação atual da aquicultura na região Norte. In: Valenti, W.C. (Ed.). Aquicultura no Brasil. CNPq, Brasília, DF, p.247-266.

Zar, J. H. 2010. Biostatistical analysis. Prentice-Hall, Upper Saddle River, NJ, 223p.

RECEIVED: 02/10/2017

ACCEPTED: 04/01/2018

ASSOCIATE EDITOR: Rodrigo do Valle 